\title{
LETTER
}

\section{HER2 expression and efficacy of T-DM1}

\author{
Filippo Montemurro \\ See related research by Perez et al., http://breast-cancer-research.com/content/16/3/R50
}

I have read with great interest the article by Edith Perez and colleagues reporting a correlation between trastuzumab-emtansine (T-DM1) efficacy and human epidermal receptor 2 (HER2) mRNA expression in the TDM4450g, phase II randomized clinical trial [1]. While acknowledging that these results are merely hypothesis generating, I believe some findings from this analysis deserve further reasoning.

Upon central histopathological review, the proportion of patients whose tumors had a normal HER2 status was evenly distributed in the two arms of the trial (about $14 \%$, see Table one in [1]). However, and not surprisingly, these HER2-normal tumors clustered entirely in the low HER2 mRNA group (Table two in [1]), where they accounted for slightly less than one-third of the cases. At the same time, the proportion of tumors with hormone receptor expression was higher in the low HER2 mRNA group $(62.1 \%$ vs. $46.6 \%)$. These data indicate that, beyond the number of HER2 receptors on the cell surface suitable for T-DM1 binding, mRNA HER2 levels are also related to different intrinsic biology and, possibly, reliance not only on HER2 but also upon other regulatory pathways such as hormone-receptor signaling [2].

In other terms, the efficacy of T-DM1 over docetaxeltrastuzumab was compared in two biologically different groups of patients, one of which was enriched with true HER2-positive tumors, and the other being a mix of HER2-negative and HER2-positive tumors at the lower end of the spectrum to define HER2-positivity. I therefore believe the extremely interesting finding of this analysis is the comparable activity of T-DM1 and docetaxel-trastuzumab in the low mRNA HER2 group, paralleled with reduced toxicity. Indeed, a combined rate of response of $11 \%$ was reported in the TDM4258 and TDM437g phase II trials in 36 heavily pretreated women whose tumor turned out to be HER2 normal by central reanalysis [3,4].
Should an activity of T-DM1 comparable with that of conventional chemotherapy be confirmed in tumors with low HER2 expression, even in those not fulfilling the conventional criteria for HER2 positivity, this would translate into an increased number of patients benefiting from this agent that, by virtue of its mechanism of action, has shown to be excellently tolerated.

\section{Abbreviations}

HER2: Human epidermal receptor 2; TDM-1: Trastuzumab-emtansine.

\section{Competing interests}

In the past 5 years FM has been a member of the Speaker's Bureau for Glaxo SmithKline S.p.A. and Hoffmann la Roche S.p.A.

Published online: 03 December 2014

\section{References}

1. Perez EA, Hurvitz SA, Amler LC, Mundt KE, Ng V, Guardino E, Gianni L: Relationship between HER2 expression and efficacy with first-line trastuzumab emtansine compared with trastuzumab plus docetaxel in TDM4450g: a randomized phase II study of patients with previously untreated HER2-positive metastatic breast cancer. Breast Cancer Res 2014, 16:R50.

2. Montemurro F, Di CS, Arpino G: Human epidermal growth factor receptor 2 (HER2)-positive and hormone receptor-positive breast cancer: new insights into molecular interactions and clinical implications. Ann Oncol 2013, 24:2715-2724.

3. Burris HA III, Rugo HS, Vukelja SJ, Vogel CL, Borson RA, Limentani $\mathrm{S}$, Tan-Chiu E, Krop IE, Michaelson RA, Girish S, Amler L, Zheng M, Chu YW, Klencke B, O'Shaughnessy JA: Phase II study of the antibody drug conjugate trastuzumab-DM1 for the treatment of human epidermal growth factor receptor 2 (HER2)-positive breast cancer after prior HER2-directed therapy. J Clin Oncol 2011, 29:398-405.

4. Krop IE, Beeram M, Modi S, Jones SF, Holden SN, Yu W, Girish S, Tibbitts J, Yi JH, Sliwkowski MX, Jacobson F, Lutzker SG, Burris HA: Phase I study of trastuzumab-DM1, an HER2 antibody-drug conjugate, given every 3 weeks to patients with HER2-positive metastatic breast cancer. J Clin Oncol 2010, 28:2698-2704.

doi:10.1186/s13058-014-0478-7

Cite this article as: Montemurro: HER2 expression and efficacy of T-DM1. Breast Cancer Research 2014 16:478.

\footnotetext{
Correspondence: filippo.montemurro@ircc.it

Unit of Investigative Clinical Oncology (INCO), Fondazione del Piemonte per I'Oncologia, Candiolo Cancer Institute (IRCCS), Strada Provinciale 142, Km 3.95, Candiolo 10060, Italy
} 